\title{
The Care of a Jehovah's Witness with Life-threatening Anemia Refusing Ventilator Care
}

\author{
- A Case Report- \\ Ji Hyeon Lee, M.D., So Ron Choi, M.D., Ph.D., Young Jhoon Chin, M.D., Ph.D., Soo Il Lee, M.D., Ph.D., \\ Chan Jong Chung, M.D., Ph.D., Jong Hwan Lee, M.D., Ph.D. and Seung Cheol Lee, M.D., Ph.D. \\ Department of Anesthesia and Pain Medicine, Dong-A University Hospital, Busan, Korea
}

\begin{abstract}
Jehovah's Witnesses refuse the transfusion of blood and blood products, even when it can be lifesaving. Their religious conviction against receiving blood can create a difficult clinical dilemma, particularly in the life threatening situations. We report a case of a 42-year-old female Jehovah's Witness patient who had life-threatening anemia after postpartum hemorrhage. Despite severe anemia, she had a good postoperative recovery without complications.
\end{abstract}

Key Words: anemia, blood transfusion, Jehovah’s witness, postpartum hemorrhage.

Jehovah's witnesses accept most medical treatments, surgical procedures and the administration of fluids, such as crystalloids, colloids and starch. However, they refuse to accept the transfusion of whole blood, packed red cells, platelets, white cells or plasma. A refusal to receive blood or blood products can complicate the treatment of Jehovah's witnesses when a medical practitioner is faced with severe hemorrhage.

We report the survival of a Jehovah's witness with a lifethreatening postpartum hemorrhage, who was not treated with blood-related products. Although bloodless medicine, such as pretreatment with erythropoietin, ventilator care, and acute normovolemic hemodilution (ANH), were not performed, she had a better recovery than expected.

\section{CASE REPORT}

A 42-year-old female Jehovah's witness was admitted to an emergency room at an outside hospital due to life-threatening postpartum hemorrhage. The patient underwent a cesarean section at 40 weeks of gestation without preoperative manage-

Received on November 2, 2009, Accepted on March 8, 2010

Correspondence to: So Ron Choi, Department of Anesthesia and Pain Medicine, Dong-A University Hospital, 1, Dongdaesin-dong 3-ga, Seo-gu, Busan 602-715, Korea

Tel: 82-51-240-5390, Fax: 82-51-247-7819

E-mail: choisr@dau.ac.kr

This study was supported by research fund from Dong-A University. ment, such as iron and erythropoietin supplementations. After surgery, a sustained hemorrhage occurred and her hemoglobin $(\mathrm{Hb})$ level fell from 9.7 to $6.0 \mathrm{~g} / \mathrm{dl}$. A transfusion was recommended but she refused to accept all blood products, including coagulation factors and autologous transfusion, due to her religious beliefs. During transport to hospital, she reported no loss of consciousness and was hemodynamically stable. Upon arrival at the emergency room, blood pressure (BP) and heart rate (HR) was 90/60 $\mathrm{mmHg}$ and 150 beats/min, respectively. The admitting $\mathrm{Hb}$ and Hct levels were $5.1 \mathrm{~g} / \mathrm{dl}$ and $14.7 \%$, respectively, and the chest X-ray was normal. The other laboratory investigations revealed a platelet (PLT) level, prothrombin time (PT) and activated partial thromboplastin time (aPTT) of $202,000 / \mathrm{mm}^{3}, 16 \mathrm{~s}$ (INR 1.36) and $36.3 \mathrm{~s}$, respectively.

Because the vaginal hemorrhage was continuous, a hysterectomy was performed under general anesthesia. Before surgery, she stated that she would not accept any treatments with blood and blood-related products, even in life-threatening circumstances. Preoperatively, erythropoietin was administered subcutaneously at a dose of 8,000 IU.

Upon arrival in the operation room, her blood pressure, heart rate, respiratory rate and body temperature were 95/60 $\mathrm{mmHg}, 160$ beats/min, 30 breath/min, and $37.5^{\circ} \mathrm{C}$, respectively. Following pre-oxygenation with $100 \%$ oxygen, endotracheal intubation was facilitated with etomidate $15 \mathrm{mg}$ and rocuronium $50 \mathrm{mg}$. After intubation, mechanical ventilation with $\mathrm{O}_{2}$-Air- 
Table 1. Arterial Blood Gas Analyses during the Perioperative and Intraoperative Periods

\begin{tabular}{lcccc}
\hline \hline & $\begin{array}{c}\text { Emergency } \\
\text { room }\end{array}$ & $\begin{array}{c}\text { After } \\
\text { induction }\end{array}$ & $\begin{array}{c}1 \mathrm{hr} \\
\text { post-surgical } \\
\text { incision }\end{array}$ & $\begin{array}{c}7 \mathrm{hr} \\
\text { post-end of } \\
\text { operation }\end{array}$ \\
\hline $\mathrm{pH}$ & 7.49 & 7.43 & 7.29 & 7.40 \\
$\mathrm{PaCO}_{2}(\mathrm{mmHg})$ & 32.5 & 25 & 39 & 31.9 \\
$\mathrm{PaO}_{2}(\mathrm{mmHg})$ & 75.3 & 265 & 304 & 173.4 \\
$\mathrm{Base}$ excess $(\mathrm{mM} / \mathrm{L})$ & 0.8 & -8.4 & -7.3 & -6.9 \\
$\mathrm{O}_{2}$ sat $(\%)$ & 96.2 & 100 & 100 & 99.2 \\
\hline
\end{tabular}

Sevoflurane $\left(\mathrm{FiO}_{2}\right.$ 0.6) was applied to the patient and a central venous pressure (CVP) of $5 \mathrm{mmHg}$ was observed at the time of the surgical incision.

Thirty minutes after the surgical incision, the hematoma was removed and her blood pressure and heart rate were 70/50 $\mathrm{mmHg}$ and 160 beats/min, respectively. After loading $300 \mathrm{ml}$ of crystalloid, her vital signs were stabilized. During the operation, her blood pressure was between 120/70 $\mathrm{mmHg}$ and $95 / 50 \mathrm{mmHg}$, heart rate between 120 beats/min and 135 beats/min and temperature between $37.5^{\circ} \mathrm{C}$ and $36.5^{\circ} \mathrm{C}$. In order to provide adequate fluid management, the CVP was monitored and maintained at 7-9 $\mathrm{mmHg}$. Arterial blood gas analysis was used to evaluate the patient's condition (Table 1).

During surgery, inotrope (dopamine) was infused with 3-5 $\mu \mathrm{g} / \mathrm{kg} / \mathrm{min}$ continuously to ensure adequate end-organ perfusion. The anesthesia and surgery duration were $120 \mathrm{~min}, 95$ min respectively. Her fluid intake was a total of $2,100 \mathrm{ml}$ of crystalloid and $1,000 \mathrm{ml}$ of hetastarch. Her urine output was $600 \mathrm{ml}$ and blood loss was $800 \mathrm{ml}$.

At the end of surgery, her blood pressure and heart rate was $110 / 60 \mathrm{mmHg}$ and 120 beats/min, respectively, and dopamine was stopped. Postoperatively, she was admitted to the intensive care unit (ICU) without extubation and sedated with midazolam. Her post-operative Hct levels were $6.5 \%$ and $\mathrm{Hb}$ level was $2.2 \mathrm{~g} / \mathrm{dl}$. The chest $\mathrm{X}$-ray did not show specific findings. Her family did not want mechanical ventilation due to the high cost. A decision was made not to apply ventilator care because self respiration and consciousness had recovered, and her blood pressure and respiration were stable. Instead of it, $7 \mathrm{~L} / \mathrm{min}$ of oxygen was supplied via a T-piece.

Erythropoietic therapy $(8,000 \mathrm{IU}, \mathrm{SC})$ and vitamin $\mathrm{K}$ were started on alternate days, and iron was supplied daily to increase the red cell mass. Blood sampling was performed every second day to reduce the level of blood loss. On the 3rd postoperative day, hemodynamic stabilization was achieved and extubation was done. She recovered fully and the dopamine in-

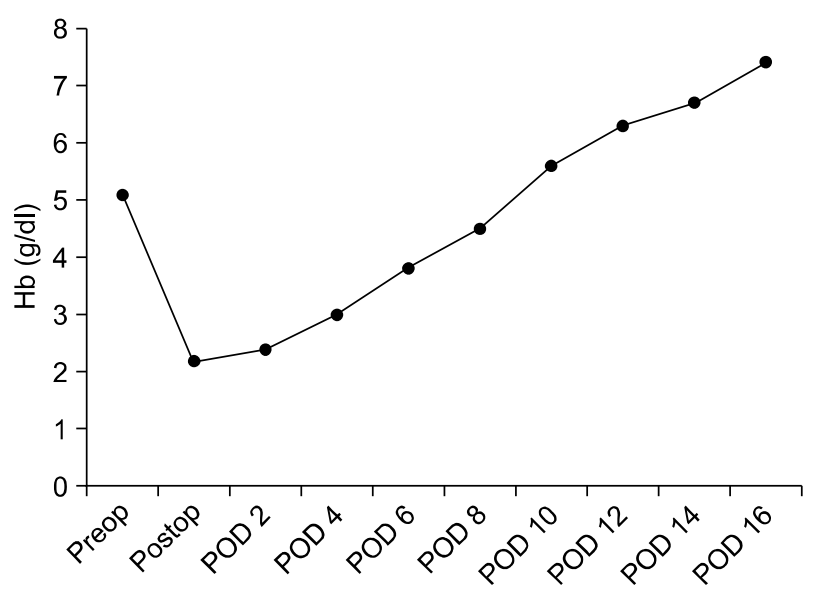

Fig. 1. $\mathrm{Hb}(\mathrm{g} / \mathrm{dl})$ level change of patient during pre and post operative period. Postoperatively, her $\mathrm{Hb}$ decreased to $2.2 \mathrm{~g} / \mathrm{dl}$. After $2 \mathrm{nd}$ postoperative day, $\mathrm{Hb}$ level increased slowly and presented 7.4 $\mathrm{g} / \mathrm{dl}$ at the 16th postoperative day.

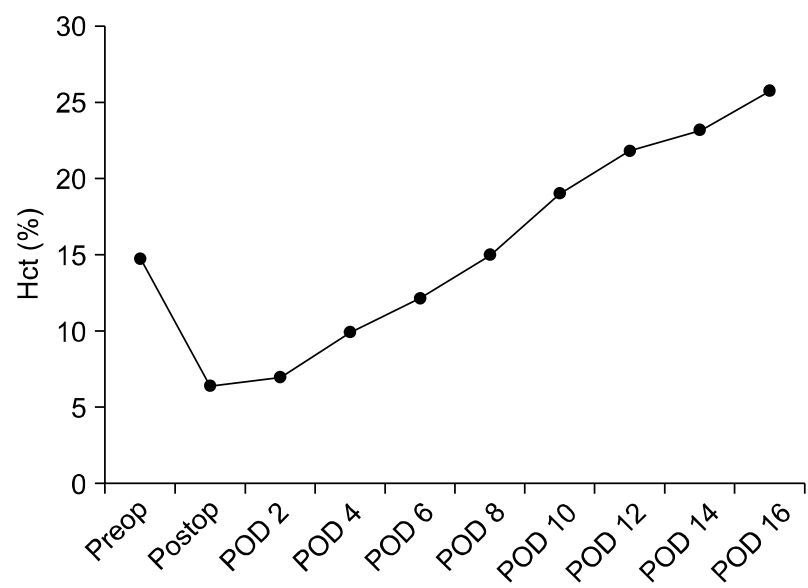

Fig. 2. Hct (\%) level change of patient during pre and post operative period. Postoperatively, her Hct dcreased to $6.5 \%$. After 2 nd postoperative day, Hct level increased slowly and presented $25.7 \%$ at the 16 th postoperative day.

fusion was stopped. Her $\mathrm{Hb}$ and $\mathrm{Hct}$ were increased slowly (Fig. 1, 2). On the 5th postoperative day, she was transferred to the general ward. On the 16th postoperative day, she discharged from hospital without complications. At discharge, her $\mathrm{Hb}$ level was $7.4 \mathrm{~g} / \mathrm{dl}$.

\section{DISCUSSION}

Blood transfusions and blood products are often given as a life-saving measure to patients with critical illnesses. However, some patients, such as Jehovah's witnesses, may refuse their administration due to their religious beliefs. A refusal to re- 
ceive blood or blood products can complicate the treatment of Jehovah's witnesses when an obstetrician is faced with severe obstetric hemorrhage.

Jehovah's witnesses accept most medical treatments, surgical procedures and administration of fluid, such as crystalloids, colloids and starch. ${ }^{1)}$ However, they find the transfusion of whole blood, packed red cells, platelets, white cells or plasma unacceptable. $^{2)}$ On the other hand, products such as albumin, immunoglobulin, vaccines and clotting factors are viewed as a matter of individual choice. ${ }^{2,3)}$ Predonation of blood is unacceptable, even though many Jehovah's witnesses will accept peri- and postoperative autologous procedures based on a personal decision, particularly when the removal and transfusion can be managed via a continuous circuit. $^{1,4)}$ Therefore, each patient's needs, values and beliefs must be assessed before treatment, and the clinician is obliged to respect patient's preferences.

In our case, the patient refused all blood products including coagulation factors and autologous transfusion due to her religious beliefs. The patient's $\mathrm{Hb}$ level decreased to $2.2 \mathrm{~g} / \mathrm{dl}$ postoperatively. The decrease in $\mathrm{Hb}$ was most likely the result of uterine bleeding after the cesarean section. Carson JL et al. reported mortality and morbidity in patients with very low postoperative $\mathrm{Hb}$ levels. ${ }^{5}$ ) They stated that although the risk of death was low in patients with $\mathrm{Hb}$ levels of 7.1 to $8.0 \mathrm{~g} / \mathrm{dl}$, it was extremely high in patients below 5 to $6 \mathrm{~g} / \mathrm{dl}$. Our patient with an initial and postoperative $\mathrm{Hb}$ level of 5.1 and $2.2 \mathrm{~g} / \mathrm{dl}$, respectively, was at extremely high risk. An acute reduction of blood hemoglobin concentration $<5 \mathrm{~g} / \mathrm{dl}$ may result in inadequate oxygen delivery and severe tissue hypoxia. ${ }^{4,5)}$ The treating physicians need to formulate a clinical management plan to minimize blood loss and maximize oxygen delivery.

Several strategies can be used to treat Jehovah's witnesses, including intraoperative blood salvage, minimizing metabolic demand, maximizing oxygen delivery, reducing iatrogenic blood loss, and increasing red blood cell production. ${ }^{6,7)}$ Our management plan was to optimize oxygen delivery by adequate fluid replacement, to increase cardiac output with inotrope, and use high oxygen concentrations for higher dissolved oxygen.

Many interventions can be used to minimize intraoperative blood loss. Acute normovolemic hemodilution (ANH) may be a valuable means of reducing intraoperative blood loss, but an adequate Hct level is needed and transfusion must be performed via a continuous circuit. ${ }^{7}$ In our patient, Hct was too low at the beginning of surgery for this strategy to be used.

Strategies to reduce the metabolic demand include sedation, analgesics, mechanical ventilation and hypothermia. ${ }^{8)}$ Muscle paralysis with sedation and ventilatory support is effective in minimizing the oxygen uptake. ${ }^{9)}$ Controlled mild hypothermia by reducing the core temperature to $30-32^{\circ} \mathrm{C}$ has been used successfully in the management of severe anemia. However, hypothermia can have adverse effects on coagulation., ${ }^{9,10)}$ Therefore, the benefits of reducing the metabolic rate must be weighed against the risk of inducing coagulopathy and increasing blood loss. In this case, as her family did not want ventilator care, it was difficult to reduce the metabolic demand and maximize oxygen supply.

Strategies to improve oxygen delivery include maximizing blood production, increasing the cardiac output, and supplying dissolved oxygen. ${ }^{11)}$ The intravascular volume should be monitored and maintained at adequate levels. Where necessary, an inotropic agent may be used to increase the cardiac output. Increased red blood cell production can be accomplished by administering erythropoietin and supplemental iron. ${ }^{12,13)}$ Erythropoiesis is regulated by the glycopeptide erythropoietin. Binding to the BFU (burst-forming unit) and CFU (colony-forming unit) receptors of the premature erythrocytes, erythropoietin has a specific effect on the survival and maturation of precursor cells. $^{12)}$ Tissue hypoxemia represents the maximum stimulus for increased endogenous erythropoietin release. ${ }^{11-13)}$ An inadequate endogenous erythropoietin concentration has been documented in anemic and critically ill patients. Recombinant human erythropoietin (rhEPO) is accepted by most Jehovah's witnesses. The optimal dose and dosing regimen of rhEPO remain unclear, particularly when treating critically ill patients with severe anemia who refuse transfusions. However, the high-dosing strategy of rhEPO for the treatment of severe anemia has demonstrated its safety and utility. ${ }^{14)}$

We present a case of a severe anemic Jehovah's witness patient and offer an approach to their management. Minimizing the metabolic demand, maximizing oxygen delivery, reducing the iatrogenic blood loss, and increasing red blood cell production are important factors in management.

\section{REFERENCES}

1) Marsh JC, Bevan DH: Haematological care of the Jehovah's witness patient. Br J Haematol 2002; 119: 25-37.

2) Doyle DJ: Blood transfusions and the Jehovah's witness patient. Am J Ther 2002; 9: 417-24.

3) Gohel MS, Bulbulia RA, Slim FJ, Poskitt KR, Whyman MR: How to approach major surgery where patients refuse blood 
transfusion (including Jehovah's Witnesses). Ann R Coll Surg Engl 2005; 87: 3-14.

4) Remmers PA, Speer AJ: Clinical strategies in the medical care of Jehovah's Witnesses. Am J Med 2006; 119: 1013-8.

5) Carson JL, Noveck H, Berlin JA, Gould SA: Mortality and morbidity in patients with very low postoperative $\mathrm{Hb}$ levels who decline blood transfusion. Transfusion 2002; 42: 812-8.

6) Goodnough LT, Shander A, Spence R: Bloodless medicine: clinical care without allogeneic blood transfusion. Transfusion 2003; 43: 668-76.

7) Shander A, Goodnough LT: Objectives and limitations of bloodless medical care. Curr Opin Hematol 2006; 13: 462-70.

8) Mann MC, Votto J, Kambe J, McNamee MJ: Management of the severely anemic patient who refuses transfusion: lessons learned during the care of a Jehovah's Witness. Ann Intern Med 1992; 117: 1042-8.

9) Kulvatunyou N, Heard SO: Care of the injured Jehovah's Witness patient: case report and review of the literature. J Clin Anesth 2004; 16: 548-53.
10) Casati V, D’Angelo A, Barbato L, Turolla D, Villa F, Grasso MA, et al: Perioperative management of four anaemic female Jehovah's Witnesses undergoing urgent complex cardiac surgery. Br J Anaesth 2007; 99: 349-52.

11) Digieri LA, Pistelli IP, de Carvalho CE: The care of a child with multiple trauma and severe anemia who was a Jehovah's Witness. Hematology 2006; 11: 187-91.

12) Ball AM, Winstead PS: Recombinant human erythropoietin therapy in critically ill Jehovah's Witnesses. Pharmacotherapy 2008; 28: 1383-90.

13) Silver M, Corwin MJ, Bazan A, Gettinger A, Enny C, Corwin HL: Efficacy of recombinant human erythropoietin in critically ill patients admitted to a long-term acute care facility: a randomized, double-blind, placebo-controlled trial. Crit Care Med 2006; 34: 2310-6.

14) Schälte G, Janz H, Busse J, Jovanovic V, Rossaint R, Kuhlen $\mathrm{R}$ : Life-threatening postoperative blood loss in a Jehovah's Witness, treated with high-dose erythropoietin. Br J Anaesth 2005; 94: 442-4. 